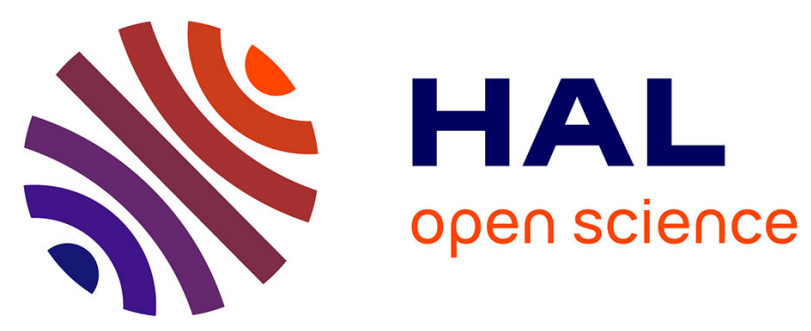

\title{
Role of substrate properties in the provision of multifunctional green roof ecosystem services
}

\author{
J.-C. Lata, Y. Dusza, Luc Abbadie, S. Barot, D. Carmignac, E. Gendreau, Y. \\ Kraepiel, J. Mériguet, E. Motard, X. Raynaud
}

\section{- To cite this version:}

J.-C. Lata, Y. Dusza, Luc Abbadie, S. Barot, D. Carmignac, et al.. Role of substrate properties in the provision of multifunctional green roof ecosystem services. Applied Soil Ecology, 2018, 123, pp.464-468. 10.1016/j.apsoil.2017.09.012 . hal-01685372

\section{HAL Id: hal-01685372 https://hal.sorbonne-universite.fr/hal-01685372}

Submitted on 16 Jan 2018

HAL is a multi-disciplinary open access archive for the deposit and dissemination of scientific research documents, whether they are published or not. The documents may come from teaching and research institutions in France or abroad, or from public or private research centers.
L'archive ouverte pluridisciplinaire HAL, est destinée au dépôt et à la diffusion de documents scientifiques de niveau recherche, publiés ou non, émanant des établissements d'enseignement et de recherche français ou étrangers, des laboratoires publics ou privés. 

4

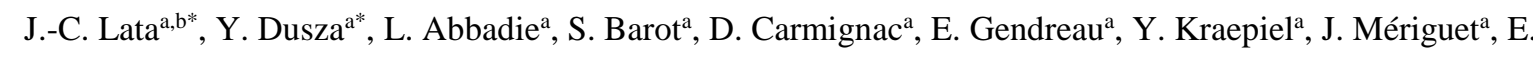 \\ Motard $^{\mathrm{a}}$, X. Raynaud ${ }^{\mathrm{a}}$
}

aSorbonne Universités, UPMC Univ Paris 06, IRD, CNRS, INRA, Univ Paris Diderot Paris 07, UPEC, UMR 7618, Institute of Ecology and Environmental Sciences - Paris, Tour 44-45, 4 place Jussieu, 75005 Paris, France

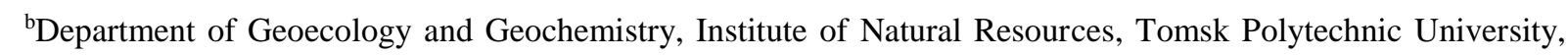
30, Lenin Street, Tomsk 634050, Russia *equal contributions

Corresponding author: Jean-Christophe Lata. Tel.: +33144274742

E-mail address: jean-christophe.lata@upmc.fr (J.-C. Lata)

\title{
ABSTRACT
}

Urban ecosystems are increasingly recognized as key providers of ecosystem services. Among them, green roofs are particularly fashionable, and are in high demand by citizens, politicians, urban planners and architects. Surprisingly, the functioning of green roofs and the impact of substrate type have been so far poorly studied and impede to optimize a green roof and its substrate to provide targeted services. This article thus discusses the different types of substrate that can be used for green roof and outlines the possible consequences for green roof functioning.

\section{Past and current green roofing}

Growing plants on roofs is an ancient practice. The Hanging Gardens of Babylon, built more than 2500 years ago, are probably the best known and oldest example, while grassed roofs of traditional Scandinavian dwellings have been regularly used to ensure thermal insulation under wet and cold climates (Dunnett and Kingsburry, 2008). While roofing had historically a protective role for buildings, roofs appear as a new space to be vegetated in large western cities since the second half of the 19th century and the development of roof terraces. During the first half of the 20th century, structures such as hanging gardens, festive terraces or restaurants developed on the roofs of cities. In the Thirties, the roofs were considered as the fifth façade of buildings as mentioned in "five 
points of modern architecture", published in 1927 by Le Corbusier and Pierre Jeanneret. However, the 1950s and the associate quick succession of urban plans marked a halt to the investment of roofs by vegetation. The current concept of green roof only emerged during the 1970s and 1980s. These years were characterized by the emergence of environmental concerns at an international level. Reports such as "The limits to growth" (1972, commissioned by the Club of Rome), or "Our common future" (1987, Brundtland report of the World Commission on Environment and Development) have led to the notion of sustainable development. In this context, Germany decided to launch an active policy for the development of environmental technologies and public policies (Oberndorfer et al., 2007), which has favoured the emergence of modern green roofs. This has led to the adoption by Germany in 1982 of its first professional rules for green roofing (FLL, 2010).

\section{What constraints on and caused by green roof substrates?}

Vegetated roofs are intended to reintroduce a living component in cities while integrating building structural constraints. Two of these constraints have guided the development of roofing vegetation technologies. The first concerns the need to maintain roof water-tightness despite the presence of roots. Above all, the fundamental role of a roof is the protection it offers to people and objects. The problem has been solved by the development of anti-root membranes associated with conventional roof protections (bituminous layers in particular). The second constraint is that of weight. At a time when the precision of architectural techniques makes it possible to precisely calculate the loads supported floor by floor, little margin is provided for roofs except for the snow load or other technical elements. In the 1970s, while some companies had already developed suitable membranes and lightweight substrates, several German studies have shown that green roofs are likely to bring environmental benefits. This includes limiting rainfall run-off to storm sewer pipes, but also thermal protection of buildings (Dunnett and Kingsburry, 2008).

Because the issues of roof overload and water-tightness are so crucial to the integrity of buildings, but also to the comfort and safety of people who live or work there, the vegetation market for roofs has been structured around these constraints. The substrates are not only light but also have to be shallow, leading to the existence of green roofs whose thickness in some case may not exceed $2 \mathrm{~cm}$. However by doing this, this also creates a new constraint in the limited choice of plants species that must be suitable for both shallow substrates and drought conditions. These conditions of restricted root development and poor water reserve, associated with significant sun exposures and potentially high windiness (Cao et al., 2013), create unfavourable growing conditions for many plant species. Species of the genus Sedum, from the family Crassulaceae, in other words succulent plants, 
respond to these expectations: they have restricted root system, their metabolism limit water loss through transpiration (Ting, 1985) and they can store water in their succulent leaves (Sayed, 2001). However, these Sedum species are not exempt from high mortality rates (Durhman et al., 2007) and the counterpart of the success of Sedum / artificial substrate association is that it constitutes the vast majority of green roofs in the world, leading to poor plant diversity, but also to limited plant and substrate functional diversity.

\section{What is a green roof substrate?}

As the greening of roofs is closely associated with the waterproofing and roofing sectors, the term "layers" refers to the different components of green roofs (Berardi et al., 2014). In fact, several technical layers are necessary before any revegetation (Vijayaraghavan, 2016). Green roof will consist of at least waterproofing and anti-root membranes, to which, according to the manufacturers, may be added various layers of insulation, drainage or water retention. Finally, the terms growth layer and vegetation layer are regularly used, both in the technical and scientific literature, to evoke the soil or substrate and the vegetation used. The composition of the growth layer (or growth substrate) reflects the search for lightness and is characterized by the artificial mixing of mineral and organic compounds (Sutton et al., 2015). There are two types of mineral elements. These are primarily volcanic rocks, such as pumice or pozzolan, or artificial elements, such as expanded clay or expanded shale. Some substrates also mix these different elements. All these natural or artificial materials have the particularity of being highly porous, and therefore light (Massazza, 1998), although in varying degrees. While porosity of perlite is generally close to $30 \%$ of its total volume (Vijayaraghavan and Raja, 2014), artificial materials such as expanded clay can exceed $80 \%$ (Berretta et al., 2014). The organic part of the substrates aims to provide the nutrients needed for plant development (including through the promotion of soil biodiversity and its associated functions) and is usually peat (Nardini et al., 2011) or compost from recycled organic waste. The use of high organic matter substrates (or even of natural soils) is however subject to controversies (Best et al., 2015). On the one hand, their use enhances the soil micro- and macro-diversity, and nutrient cycling and retention. On the other hand, there are concerns about increased roof loading and fine particle illuviation, and to unpredictable biological activities (in or above the substrate). These last concerns have led so far industry professionals to strongly discourage the use of high organic matter substrates or natural soils, in particular for maintenance reasons (e.g. removal of opportunistic ruderals plant species).

Depending on the country of origin (e.g. French, German or American policies), the proposed proportions of mineral matter is ca. $70-95 \%$, and thus ca. 5 to $30 \%$ of organic matter. The high proportion of mineral material 
has two explanations. On the one hand, organic matter is generally denser than mineral portions. Chambers et al. (2010) estimated that peat density can reach $2000 \mathrm{~kg} \cdot \mathrm{m}^{-3}$, when that of expanded clay usually don't exceed 700 kg.m $\mathrm{m}^{-3}$ (Ardakani and Yazdani, 2014). The other explanation is that a too rich substrate would lead to a rapid leaching of nutrients, which would be a source of carbon and nitrogen pollution for runoff water (Rowe et al., 2006). For the same reasons, rapidly decomposing peat is particularly deprecated (Nagase and Dunnett, 2011).

The massive incorporation of porous materials into the substrates has the effect of reducing their density, in ranges of ca. 0.6-1 t.m $\mathrm{m}^{-3}$ when dry and 0.8-1.6 t.m $\mathrm{m}^{-3}$ when water-saturated. While these substrates have long been the only ones available on the market, the present trend is for diversification. While soils are explicitly excluded from the occupational rules for most systems, recycled materials such as crushed bricks or tiles develop gradually (Ondoño et al., 2015), with the advantage of being both local and potentially mild materials (Graceson et al., 2014). Moreover, the need for more functional diversity led to the definition of different green roof typologies based mainly on their depth, the substrate type used for the growth layer, and therefore the induced load for the building, but also on the type of vegetation and the degree of maintenance required. These different systems are called: extensive (light substrate, no watering, thickness of substrate of 4-15 cm, mainly succulent plants); semi-intensive (light substrate, watering, thickness of substrate of $12-30 \mathrm{~cm}$, grasses or low-development shrubs); and intensive (natural soil, watering, thickness of substrate $<30 \mathrm{~cm}$, unlimited choice of plants). While the majority of the systems sold are extensive, there is a growing rejection of the "all Sedum" (i.e. very shallow extensive roof, only planted with Sedum species) and an increased demand for systems with a greater variety of species, pushing towards the development of "semi-intensive" offers. This evolution, which is still difficult to quantify, echoes the increasing number of environmental approaches taken by local and regional authorities (e.g. in France) to increase the diversity of plant species and the depth of substrate on the roofs, in a context where 75\% orders are public organisms (CSTB 2008).

\section{What ecosystem services are provided by green roof substrates?}

The reasons for the growing popularity of green roofs are the same as those that prevailed when they were (re)created in the 1980s: the multiplicity of environmental services they provide, highlighted both in terms of supply and demand (Dusza et al., 2015). Because green roofs are a combination of abiotic and biotic components interacting with their environment, and because these benefits are "services people obtain from ecosystems" in the sense of the Millennium Ecosystem Assessment (2005), green roofs provide numerous ecosystem services (Table 1) including important cultural services (Lee et al., 2015). 
The ecosystem services associated with green roofs are widely put forward, both at the level of prime contractors and owners, and explain to a large extent their popularity worldwide. Green roofs are subject to very wide disciplinary appropriations but are often relatively remote from the biology or ecology fields. The discipline fields most represented are that of energy and physics, followed by hydrology (Blank et al., 2013). De facto this diversity of disciplinary fields reflects the diversity of services that can be provided by green roofs. The great majority of publications, however, rely on a similar initial objective, namely to determine the effectiveness of green roofs in relation to the ecosystem service studied.

In the realization of these services, and the trade-offs between services and disservices, the role of substrate is decisive, and in particular for two of its characteristics: substrate composition and substrate depth. First, substrate composition affect substrate fertility and the availability of nutrients to plants; however rich substrates while benefiting plants also lead to high carbon and nitrogen leaching rates (Beecham and Razzaghmanesh, 2015). Beyond nutrients, the risk of heavy metals release from substrates is increased in the presence of recycled materials such as broken tiles or bricks (Alsup et al., 2009). Substrate porosity affect substrate capacity to retain water as green roof manufactured substrates as pozzolan tend to be globally highly porous to gain lightness, while in natural soils the water retention is driven by the pore size distribution (Graceson et al., 2013). The intraand inter-particle porosity are thus two important factors to be taken into account in order to promote water retention. Water retention also affects substrate temperature that can affect both plant root growth and functioning and building cooling. In this case, a more porous substrate likely leads to a better building cooling (Lin and Lin, 2011). However, as air is a better thermal insulator than water, a trade-off exists between the substrate overall porosity, substrate overall capacity to retain water, and irrigation frequencies. Efforts are currently being made on searching different alternatives to design substrates from key components to achieve desirable characteristics and thus better services. One example is the incorporation of substrate additives (e.g. seaweed) that can enhance water retention and sorption capacity, in particular for metal ions (Vijayaraghavan et al., 2015). Biochar addition in particular is viewed, and has been tested recently, as a mean to increase water holding capacity and plant available water without increasing substrate weight loading (Cao et al., 2014; Kuoppamäki and Lehvävirta, 2016) even if the properties of biochar can vary considerably (Kuoppamäki et al., 2016).

Second, substrate depth by increasing substrate volume could, in absolute, linearly increase the effects of substrate composition above-mentioned. The effects however are often unclear, perhaps due to the limited number of available studies, and to the fact that few studies have attempted to integrate several ecosystem 
services simultaneously. Generally, deeper substrates favor plant growth and water retention (Nagase and Dunnett, 2010; Buccola and Spolek, 2010) even if they can be detrimental because of higher soil moisture to certain plant species such as stress tolerant species (Rowe, 2015). However, deeper substrates can lead to higher nitrogen and carbon leaching and thus decrease the quality of runoff water (Seidl et al., 2013), or have no effect (Razzaghmanesh et al., 2016) e.g. by lessening water leaching and increasing nitrogen and carbon holding (Vijayaraghavan, 2016). In the end, two mechanisms are confounded when depth of green roof's substrate is increased. The quantity of leachable material increases, but the larger water retention allows a longer presence within the substrate, which would favor a greater sorption by the substrate or a greater absorption by plants.

\section{Conclusion: what future researches on green roof substrates?}

Important gaps exist in the knowledge of the role of substrates on ecosystem services provided by green roofs. For instance, very few authors have studied the effect of substrate composition on evapotranspiration mechanisms. To our knowledge, no published study has evaluated the influence of substrate depth, substrate composition or the choice of plant species on air pollution, nor on the services of supports of biodiversity or pollination. No study ever projected to study the evolution of a substrate's diversity in terms of microorganisms e.g. the ones involved in the realization of the nitrogen cycle. This is of great importance as substrates, that differ from natural soils in their mineral composition but also in their organic compounds, can lead to particular abundances, activities and strategies (such as oligotrophic vs. copiotrophic) of microorganisms (Ditterich et al., 2016). Beyond studying the successions of microbial communities within substrates, the delivery of ecosystem services by green roofs could benefit from studies focusing on i) how exactly certain substrate components can modify microbial communities and functions (e.g. the addition of biochar can promote plant performance by increasing diversity and modifying metabolic potential in the rhizosphere microbiome - Kolton et al., 2017), and ii) how harsh environments as green roofs could be improved by manipulating microbial communities such as mycorrhizal fungi and microbial mixtures (Molineux et al., 2014; John et al., 2017).

Project managers as well as building owners indeed agree that there is a lack of tools to design and manage green roofs associated with "quality" ecosystem services. Studies that explicitly sought to evaluate the effect of vegetation type, composition, or substrate depth on ecosystem functions and services provided by green roofs are scarce (e.g. Graceson et al., 2014; Young et al., 2014; Aloisio et al., 2016; Eksi and Rowe, 2016; Ondoño et al., 2016). In relation to substrate (composition or depth combined), there are about fifteen studies concerning thermal services, about ten concerning the reduction of runoff, a dozen concerning water quality, only one 
concerning the quality of air, none concerning other services. How can this low interest in the relationships between the components of a green roof and service levels be explained? A first explanation is the technical nature of green roofs. As mentioned above, the vast majority of commercialized green roofs are off-the-shelf systems, the design of which is highly standardized. This explains the homogeneity of systems throughout the world, and the scarcity of comparative studies. Moreover, the influence of the components of a green roof on the associated services is by essence multidisciplinary, and this also explains a part of the apparent scarcity of the specialized literature.

In the end, one of the main stumbling block is that the variable influence of certain components of green roofs on the expected services underlines the possibility of trade-offs between these services. In other words, optimizing a particular service is likely to reduce the level of another service. This possibility of compromise results mainly from the cycles of nutrients and water within a green roof. First and foremost, it is necessary to avoid as much as possible the flow of water in liquid form while promoting its evacuation in gaseous form via evapotranspiration. Second, it is necessary to facilitate the storage of carbon and nitrogen by plants and the substrate by limiting substrate leaching. Water cycle and nutrient cycle are intrinsically linked through different ecosystem functions. For example, transpiration depends on leaf area and the total biomass of the plants, which are themselves the result of the availability of nutrients, this ultimate being determined by the moisture of the substrate, conditioned by plant transpiration.

To better understand these trade-offs, while information on the links between components of a green roof substrate and the functions or services it fulfills remains fragmented, studies that have sought to cross just two of these components are rare. Until recently (Dusza et al., 2017), no study had evaluated the influence of interactions between substrate depth, substrate composition, and plant species on any of the functions or services of a green roof (Figure 1). In 2015, Lundholm was the first author to explicitly use the term "multifunctionality" in the context of green roofs. By observing how plant species, in monoculture or in combination of plants, simultaneously alter substrate temperature, retention and biomass production, Ludholm has established an index of multifunctionality representing an average of functions. Lundholm considered three types of treatment in relation to the desired services: the least and most effective for a given service, as well as those with the highest multifunctionality index. This approach is very innovative in the disciplinary field of green roofs and calls for more multifunctionality studies while we now know that substrate-plant interactions induce trade-offs between ecosystem functions, and that substrate type and depth interactions are major drivers for green roof multifunctionality (Dusza et al., 2017). 


\section{Acknowledgements}

We would like to thank the Mission Economie de la Biodiversité of CDC-Biodiversité (Caisse des Dépôts group) and the City of Paris for funding. We would also like to thank an anonymous referee for his constructive comments on an earlier draft.

\section{References}

Aloisio, J.M., Tuininga, A.R., Lewis, J.D., 2016. Crop species selection effects on stormwater runoff and edible biomass in an agricultural green roof microcosm. Ecological Engineering, 88, 20-27.

Alsup, S., Ebbs, S., Retzlaff, W., 2009. The exchangeability and leachability of metals from select green roof growth substrates. Urban Ecosystems, 13, 91-111.

Ardakani, A., Yazdani, M., 2014. The relation between particle density and static elastic moduli of lightweight expanded clay aggregates. Applied Clay Science, 93-94, 28-34.

Beecham, S., Razzaghmanesh, M., 2015. Water quality and quantity investigation of green roofs in a dry climate. Water Research, 70, 370-384.

Berardi, U., GhaffarianHoseini, A., GhaffarianHoseini, A., 2014. State-of-the-art analysis of the environmental benefits of green roofs. Applied Energy, 115, 411-428.

Berretta, C., Poë, S., Stovin, V., 2014. Moisture content behaviour in extensive green roofs during dry periods: The influence of vegetation and substrate characteristics. Journal of Hydrology, 511, 374-386.

Best, B.B., Swadek, R.K., Burgess, T.L., 2015. Soil-Based Green Roofs. In: Sutton K.R. (eds) Green Roof Ecosystems (pp. 139-174). Ecological Studies (Analysis and Synthesis), vol 223. Springer, Cham

Blank, L., Vasl, A., Levy, S., Grant, G., Kadas, G., Dafni, A., Blaustein, L., 2013. Directions in green roof research: A bibliometric study. Building and Environment, 66, 23-28.

Buccola, N., Spolek, G., 2010. A Pilot-Scale Evaluation of Greenroof Runoff Retention, Detention, and Quality. Water, Air, Soil Pollution, 216, 83-92.

Cao, J., Tamura, Y., Yoshida, A., 2013. Wind tunnel investigation of wind loads on rooftop model modules for green roofing systems, Journal of Wind Engineering, 118, 20-34.

Cao, C.T.N., Farrell, C., Kristiansen, P.E., Rayner, J.P., 2014. Biochar makes green roof substrates lighter and improves water supply to plants. Ecological Engineering, 71, 368-374. 
Chambers, F.M., Beilman, D.W., Yu Z., 2010. Methods for determining peat humification and for quantifying peat bulk density, organic matter and carbon content for palaeostudies of climate and peatland carbon dynamic. Mires and Peat, 7, 1-10.

CSTB, 2008. Centre Scientifique et technique du bâtiment, Toitures végétalisées : une contribution au développement durable. http://www.cstb.fr/archives/webzines/editions/19-fevrier-2008/toitures-vegetaliseesune-contribution-au-developpement-durable.html.

Ditterich, F., Poll, C., Pronk, G.J., Heister, K., Chandran, A., Rennert, T., Kögel-Knabner, I., Kandeler, E., 2016. Succession of soil microbial communities and enzyme activities in artificial soils. Pedobiologia, 59, 93-104.

Dunnett, N., Kingsburry, N., 2008. Planting green roofs and living walls. Timber Press Portland, London, 328pp. Durhman, A.K., Rowe, D.B., Building, S., Lansing, E., Rugh, C.L., 2007. Effect of substrate depth on initial growth, coverage, and survival of 25 succulent green roof plant taxa. HortScience, 42, 588-595.

Dusza, Y., 2017. Green roofs and ecosystem services: enhancing multifunctionality through soil-plant interactions and plant diversity. PhD Thesis, University of Pierre and Marie Curie UPMC, Paris, France.

Dusza, Y., Pacteau, C., Abbadie, L., 2015. Toitures végétalisées et services écosystémiques : vers des toituresécosystèmes (p. 117-202), in "Toit urbain : les défis énergétiques et écosystémiques d'un nouveau territoire" (Dir. Prochazka, A., Breux, S., Griffith, C., Boyer- Mercier, P.), Presses universitaires de Laval, 396 pp.

Dusza, Y., Barot, S., Kraepiel, Y., Lata, J-C., Abbadie, L., Raynaud, X., 2017. Multifunctionality is affected by interactions between green roof plant species, substrate depth, and substrate type. Ecology and Evolution, 7 , $2357-2369$.

Eksi, M., Rowe, D.B., 2016. Green roof substrates: Effect of recycled crushed porcelain and foamed glass on plant growth and water retention. Urban Forestry \& Urban Greening, 20, 81-88.

FLL, 2010. Forschungsgesellschaft Landschaftsentwicklung Landschaftsbau (Landscape, Research, Development and Construction Society). Guideline for the Planning, Execution, and upkeep of green-roof Sites. www.f-1-1.de.

Graceson, A., Hare, M., Monaghan, J., Hall, N., 2013. The water retention capabilities of growing media for green roofs. Ecological Engineering, 61, 328-334.

Graceson, A., Monaghan, J., Hall, N., Hare, M., 2014. Plant growth responses to different growing media for green roofs. Ecological Engineering, 69, 196-200.

Graceson, A., Hare, M., Hall, N., Monaghan, J., 2014. Use of inorganic substrates and composted green waste in growing media for green roofs. Biosystems Engineering, 124, 1-7. 
John, J., Kernaghan, G., Lundholm, J., 2017. The potential for mycorrhizae to improve green roof function. Urban ecosystems, 20, 113-127.

Kolton, M., Graber, E.R., Tsehansky, L., Elad, Y., Cytryn, E., 2017. Biochar-stimulated plant performance is strongly linked to microbial diversity and metabolic potential in the rhizosphere. New Phytologist, 213, $1393-1404$.

Kuoppamäki, K., Lehvävirta, S., 2016. Mitigating nutrient leaching from green roofs with biochar. Landscape and Urban Planning, 152, 39-48.

Kuoppamäki, K., Hagner, M., Lehvävirta, S., Setälä, H., 2016. Biochar amendment in the green roof substrate affects runoff quality and quantity. Ecological Engineering, 88, 1-9.

Lee, K.E., Williams, K.J.H., Sargent, L.D., Williams, N.S.G., Johnson, K.A., 2015. 40-second green roof views sustain attention: The role of micro-breaks in attention restoration. Journal of Environmental Psychology, 42, $182-189$.

Lin, Y.-J., Lin, H.-T., 2011. Thermal performance of different planting substrates and irrigation frequencies in extensive tropical rooftop greeneries. Building and Environment, 46, 345-355.

Lundholm, J.T., 2015. Green roof plant species diversity improves ecosystem multifunctionality. Journal of Applied Ecology, 52, 726-734.

Massazza, F., 1998. Pozzolana and Pozzolonaic cements (471-635) in Lea's Chemistry of Cement and Concrete (Fourth Edition), edited by Peter C. Hewlett, Oxford, (U-K), 1057 pp.

Millenium Ecosystem Assessment, 2005. Ecosystems and Human Well-Being: Synthesis. Island Press, Washington, DC.

Molineux, C.J., Connop, S.P., Gange, A.C., 2014. Manipulating soil microbial communities in extensive green roof substrates. Science of the Total Environment, 493, 632-638.

Nagase, A., Dunnett, N., 2010. Drought tolerance in different vegetation types for extensive green roofs: Effects of watering and diversity. Landscape and Urban Planning, 97, 318-327.

Nagase, A., Dunnett, N., 2011. The relationship between percentage of organic matter in substrate and plant growth in extensive green roofs. Landscape and Urban Planning, 103, 230-236.

Nardini, A., Andri, S., Crasso, M., 2011. Influence of substrate depth and vegetation type on temperature and water runoff mitigation by extensive green roofs: shrubs versus herbaceous plants. Urban Ecosystems, 15, $697-708$. 
Oberndorfer, E., Lundholm, J., Bass, B., Coffman, R.R., Doshi, H., Dunnett, N., Gaffin, S., Köhler, M., Liu, K.K.Y., Rowe, B., 2007. Green roofs as urban ecosystems: Ecological structures, functions, and services. BioScience, 57, 823-833.

Ondoño, S., Martínez-Sánchez, J.J., Moreno, J.L., 2015. Evaluating the growth of several Mediterranean endemic species in artificial substrates: Are these species suitable for their future use in green roofs? Ecological Engineering, 81, 405-417.

Ondoño, S., Martínez-Sánchez, J.J., Moreno, J.L., 2016. The composition and depth of green roof substrates affect the growth of Silene vulgaris and Lagurus ovatus species and the C and $\mathrm{N}$ sequestration under two irrigation conditions. Journal of environmental management, 166, 330-340.

Razzaghmanesh, M., Beecham, S., Salemi, T., 2016. The role of green roofs in mitigating Urban Heat Island effects in the metropolitan area of Adelaide Urban Forestry \& Urban Greening, 15, 89-102.

Rowe, D.B., Monterusso, M.A., Rugh, C.L., 2006. Assessment of heat-expanded slate and fertility requirements in green roof substrates. HortTechnology, 16, 471-477.

Rowe, B., 2015. Long-term Rooftop Plant Communities. In: Sutton K.R. (eds) Green Roof Ecosystems (pp. 311332). Ecological Studies (Analysis and Synthesis), vol 223. Springer, Cham

Sayed, O.H., 2001. Crassulacean Acid Metabolism 1975-2000, a checklist. Photosynthetica, 39, 339-352.

Seidl, M., Gromaire, M.C., Saad, M., De Gouvello, B., 2013. Effect of substrate depth and rain-event history on the pollutant abatement of green roofs. Environmental Pollution, 183, 195-203.

Sutton, K.R., 2015. Green Roof Ecosystems. Ecological Studies 223, Springer International Publishing Switzerland (K.R. Sutton, ed.), doi:10.1007/978-3-319-14983-7_1.

Ting, I.P., 1985. Crassulacean acid metabolism. Annual review of plant physiology, 36, 595- 622.

Vijayaraghavan, K., 2016. Green roofs: A critical review on the role of components, benefits, limitations and trends. Renewable and Sustainable Energy Reviews, 57, 740-752.

Vijayaraghavan, K., Raja, F.D., 2014. Design and development of green roof substrate to improve runoff water quality: Plant growth experiments and adsorption. Water Research, 63, 94-101.

Vijayaraghavan, K., Joshi, U.M., 2015. Application of seaweed as substrate additive in green roofs: Enhancement of water retention and sorption capacity. Landscape and Urban Planning, 143, 25-32.

Young, T., Cameron, D.D., Sorrill, J., Edwards, T., Phoenix, G.K., 2014. Importance of different components of green roof substrate on plant growth and physiological performance. Urban Forestry \& Urban Greening, 13, 507-516. 
Table 1

Ecosystem services associated with green roofs (Dusza, 2017). Service category

Expected services of green roofs

Regulation

(City scale)
Fighting urban heat island effects

Reduction of rainwater run-off

Improved water and air quality

Carbon storage

\begin{tabular}{cc}
\hline $\begin{array}{c}\text { Regulation } \\
\text { (Building scale) }\end{array}$ & $\begin{array}{c}\text { Thermal protection of building } \\
\text { Protection of waterproofing membranes }\end{array}$ \\
& $\begin{array}{c}\text { Sound protection } \\
\text { Support }\end{array}$ \\
\hline Production & Support of biodiversity \\
\hline Cultural & Urban Agriculture \\
\hline & Psychological services (resistance to stress, attention restoration)
\end{tabular}

Fig. 1.

Experimental green roof in Paris City, France, manipulating substrate type, substrate depth and plant diversity $@$

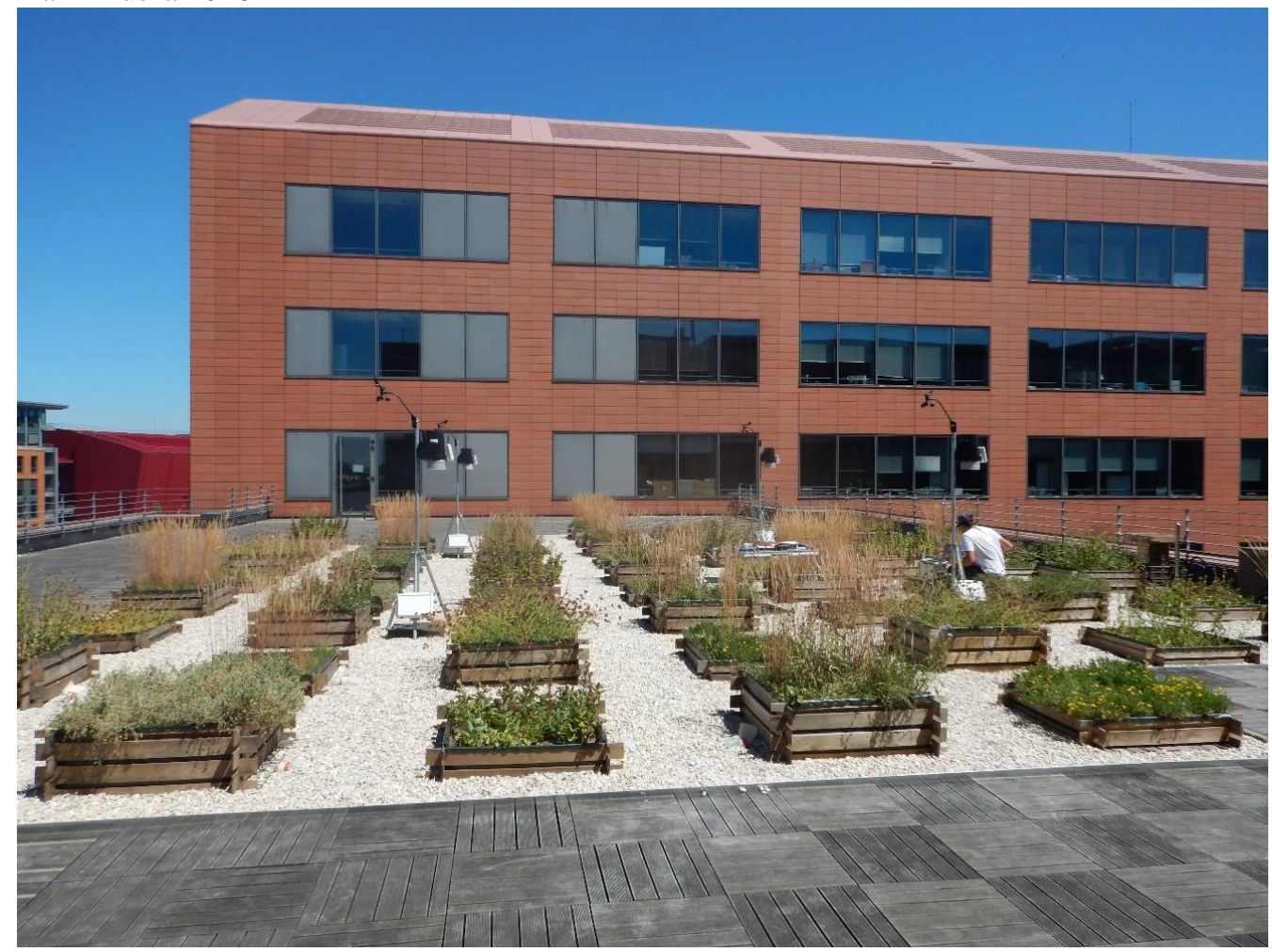

